\title{
TESTIRANJE KLASIČNIH TEORIJA STRUKTURE KAPITALA NA PRIMJERU HRVATSKIH VELIKIH PODUZEĆA
}

\section{TESTING OF CLASSICAL CAPITAL STRUCTURE THEORIES ON CROATIAN LARGE COMPANIES}

SAŽETAK: Svrha je ovog rada ispitati primjenjivost dviju dominantnih teorija strukture kapitala na primjeru hrvatskih velikih poduzeća. Riječ je o teoriji kompromisa i teoriji hijerarhije financijskih izbora, koje su prvenstveno razvijene za velika dionička društva razvijenih zemalja s tržišno orijentiranim financijskim sustavima (poput SAD-a), u kakvim uvjetima su najčešće i ispitivane. $\mathrm{U}$ ovom radu koriste se modeli razvijeni u radu Shyam-Sunder i Myers (1999) uz nužne modifikacije varijabli. Panel regresijskom analizom na uzorku od 193 velika hrvatska poduzeća za razdoblje od 2004. do 2019. godine, ispituje se efikasnost navedenih teorija, s ciljem utvrđivanja one teorije koja najbolje objašnjava financijsko ponašanje analiziranih poduzeća. Rezultati upućuju na to da se teorijom kompromisa mogu bolje objasniti formirane strukture kapitala analiziranih poduzeća, odnosno da poduzeća imaju definiranu ciljanu razinu financijskog duga kojoj konvergiraju. Teorija je efikasnija na uzorku kotiranih poduzeća, dok za nekotirana poduzeća teorija gubi eksplanatornu snagu.

KLJUČNE RIJEČI: struktura kapitala, teorija kompromisa, teorija hijerarhije financijskih izbora, zemlje u razvoju, velika hrvatska poduzeća.

SUMMARY: The purpose of this paper is to simultaneously examine the applicability of two predominant capital structure theories on large Croatian companies: the Tradeoff Theory and the Pecking Order Hypothesis. These theories are primarily developed for and most often examined on large publicly listed companies of developed countries with market-oriented financial systems (such as the US). This paper uses models developed in Shyam-Sunder and Myers (1999), with the necessary modifications of the variables. Using panel data methodology on a sample of 193 large Croatian companies for the period between 2004 and 2019, this paper investigates the performance of the two aforementioned

Dr. sc. Ena Pecina, Ekonomski fakultet Sveučilišta u Zagrebu, Trg J. F. Kennedyja 6, 10000 Zagreb, e-mail: epecina@efzg.hr 
theories, in order to determine the theory that best explains the financial behaviour of the analysed companies. The results suggest that the Trade-off theory can better explain the formed capital structures of the analysed companies, i.e. that companies have a defined target level of financial debt to which they converge. The theory is more efficient on a sample of listed companies, while for unlisted companies the theory loses its explanatory power.

KEY WORDS: Capital Structure, Trade-off Theory, Pecking Order Hypothesis, emerging markets, large Croatian companies.

\section{UVOD}

Pojam strukture kapitala odnosi se na mogućnosti dugoročnog financiranja poslovanja poduzeća, pri čemu se dominantno promatra odabir između dva osnovna oblika kapitala: vlasničke glavnice i dugoročnih dugova (Pecina, 2018). Oblikovanje strukture kapitala zauzima važno mjesto u domeni financijskog menadžmenta, budući da se konkretnim odabirom financiranja uspostavlja određeni trošak kapitala, te se, posljedično, utječe na ekonomsku vrijednost poduzeća.

Začetnicima moderne teorije strukture kapitala smatraju se Franco Modigliani i Merton H. Miller, koji su svojim radom 1958. godine postavili temelje intenzivnog izučavanja ovog područja. U svom radu predstavili su model irelevantnosti strukture kapitala prema kojemu, u uvjetima savršenog tržišta, oblikovanjem strukture kapitala nije moguće utjecati na vrijednost poduzeća, budući da ona, prema autorima, ovisi isključivo o kapitalizaciji očekivanog poslovnog dohotka poduzeća. Unatoč nerealnim pretpostavkama modela, konkretno uvjetima savršenog tržišta koji ne vrijede u stvarnom svijetu, omogućili su drugim istraživačima da, narušavajući pojedine pretpostavke modela, pronađu one uvjete u kojima će se moći postići veća vrijednost poduzeća oblikovanjem strukture kapitala. Na taj su način do danas razvijene brojne teorije kojima se nastoje objasniti uočene formirane strukture kapitala konkretnih poduzeća. Od postojećih teorija uglavnom se izdvajaju teorija kompromisa i teorija hijerarhije financijskih izbora, kojima se uobičajeno pridodaje epitet klasičnih teorija strukture kapitala, stoga ni ne čudi njihova dominantna zastupljenost $\mathrm{u}$ empirijskim istraživanjima.

Motivacija za ovo istraživanje proizlazi iz činjenice da su teorije razvijene, te uglavnom testirane, na uzorku velikih kotiranih poduzeća razvijenih zemalja, poput Sjedinjenih Američkih Država. Te se zemlje, među ostalim, ističu visokim stupnjem razvijenosti financijskog sektora koji je prvenstveno tržišno orijentiran. U tom pogledu, teorije su razvijene pod pretpostavkom savršene ponude raznovrsnih instrumenata financiranja, pri čemu svako poduzeće može pronaći sebi adekvatan oblik financiranja. Nadalje, uvažavajući činjenicu da kotirana poduzeća imaju daleko veće mogućnosti financiranja od privatnih poduzeća, te da su suočena s manjim ograničenjima u prikupljanju financijskih sredstava, uspostavljena struktura kapitala bit će, ponajprije, rezultat njihove odabrane politike financiranja.

Cilj je ovog rada ispitati primjenjivost klasičnih teorija strukture kapitala u znatno drugačijim okvirima i na širem obuhvatu poduzeća. Ponajprije, Hrvatska se može okarakterizirati kao mala, tranzicijska zemlja, bankocentričnog financijskog sustava sa slabo razvijenim tržištem kapitala. $\mathrm{U}$ tom je smislu ponuda i raznovrsnost instrumenata financiranja ograničena te se uglavnom svodi na financiranje bankovnim kreditima. Po pitanju 
poduzeća, obuhvat je s kotiranih poduzeća proširen na poduzeća čije dionice ne kotiraju na burzi. Potonja poduzeća susreću se s većim ograničenjima u dostupnosti pojedinih oblika financiranja, što potencijalno onemogućava oblikovanje strukture kapitala u skladu s odabranom politikom financiranja. Ovakvim proširenim okvirom istraživanja namjerava se postići dvojak doprinos: (1) umanjiti jaz istraživanja područja strukture kapitala u zemljama u razvoju i u Republici Hrvatskoj u kojoj su takva istraživanja gotovo zanemarena, te (2) ispitati mogućnost primjene navedenih teorija na širem obuhvatu poduzeća u odnosu na uobičajeno velika kotirana poduzeća u dosadašnjim studijama.

Rad se sastoji od pet poglavlja. Nakon uvoda, u drugome poglavlju ukratko su predstavljeni teorijski koncepti i mogućnosti testiranja klasičnih teorija strukture kapitala: teorije kompromisa i teorije hijerarhije financijskih izbora. Treće poglavlje opisuje kriterije odabira poduzeća u uzorak, vremenski obuhvat analize, te korištenu metodologiju. Četvrto poglavlje predstavlja empirijski dio rada u kojemu se sažeto prikazuju osnovni rezultati provedenog istraživanja i daje diskusija dobivenih rezultata. Peto poglavlje sadrži zaključke rada, navodi osnovna ograničenja istraživanja te daje preporuke za buduća istraživanja područja strukture kapitala.

\section{PREGLED LITERATURE I MOGUĆNOSTI TESTIRANJA TEORIJA STRUKTURE KAPITALA}

Područje strukture kapitala već dugo vremena intrigira ekonomsku znanost, čemu svjedoči velik broj nastalih radova kojima se pokušava razjasniti kako poduzeća oblikuju svoje strukture kapitala. Unatoč brojnosti provedenih znanstvenih istraživanja, jednoznačnog odgovora još uvijek nema. O samoj kompleksnosti tematike najbolje govori izraz jednog od najvažnijih istraživača ovog područja, Stewarta Myersa (1984) koji odluke o oblikovanju strukture kapitala poduzeća naziva zagonetkom strukture kapitala (engl. the capital structure puzzle).

Začetnicima moderne teorije strukture kapitala smatraju se nobelovci Franco Modigliani i Merton H. Miller. U svom inicijalnom modelu smještenom u uvjete savršenog tržišta, pokazali su da financijska poluga nema utjecaja na vrijednost poduzeća, već ovisi isključivo o kapitalizaciji njegova poslovnog dohotka (Modigliani \& Miller, 1958). Narušavanjem pojedinih pretpostavki savršenog tržišta, stvoreni su modeli i teorije koje ipak realističnije objašnjavaju strukturiranje kapitala poduzeća. Tako su i sami Modigliani i Miller (1963) bili prvi koji su narušili pretpostavke savršenog tržišta dopustivši postojanje poreza na dobit. U svom ispravljenom radu pokazali su da će vrijednost poduzeća rasti kako raste stupanj financijske poluge poduzeća. Naime, zamjenom skupljeg (vlastitog) kapitala jeftinijim (dugovima), poduzeća mogu dodatno koristiti porezni zaklon, prema čemu slijedi da će vrijednost poduzeća biti najveća uz $100 \%$-tno financiranje dugovima, što je legalno i ekonomski gledano nemoguće (Orsag, 2015). Ovi radovi naišli su na brojne kritike, a kao jedna od važnijih ističe se činjenica da su zanemareni troškovi stečaja i drugi nedostaci zaduživanja, naglašavajući da bi oni mogli značajno izmijeniti zaključke o postojanju optimalne strukture kapitala (Mollik, 2008). Na tom tragu Kraus \& Litzenberger (1973) prvi formalno postavljaju hipotezu o postojanju optimalne strukture kapitala kao one razine duga pri kojoj su prednosti i nedostaci korištenja financijske poluge izjednačeni, čime su postavili temelje 
za razvoj teorije kompromisa. Teorija kompromisa može se smatrati generičkim terminom za skup povezanih teorija koje u svojoj osnovi polaze od prednosti i nedostataka korištenja duga u financiranju, čijim se suprotstavljenim djelovanjem uspostavlja optimalna struktura kapitala. Dominantna verzija teorije kompromisa ističe porezni zaklon kamata kao osnovnu prednost, i trošak financijskih poremećaja kao osnovni nedostatak zaduživanja, dok se kao nedostatak može istaknuti i trošak agenata ${ }^{1}$ pa je riječ o drugoj najčešćoj verziji teoriji kompromisa - teoriji agenata. Neovisno o isticanju pojedine skupine nedostataka korištenja duga u financiranju, verzijama teorije je zajedničko postojanje optimalne strukture kapitala, u kojoj je trošak kapitala najniži, i posljedično, vrijednost poduzeća najveća, a uspostavlja se u točki u kojoj su koristi i nedostaci zaduživanja izjednačeni. Ova teorija preferira i racionalizira umjereno zaduživanje poduzeća, uz koje će poduzeće iskorištavati porezni zaklon kamata i disciplinirati menadžment ${ }^{2}$, no istovremeno neće značajno povećavati rizik financijskih poremećaja i ugroziti opstanak poduzeća. Kad se teorija kompromisa pokušala ispitati na uzorku poduzeća iz prakse, nije naišla na potvrdu svojih teorijskih pretpostavki. Za razliku od teorije kompromisa, razvoj teorije hijerarhije financijskih izbora odvijao se obrnutim putem: od izučavanja prakse prema stvaranju teorijskih pretpostavki. Naime, Donaldson (1961) je u svojoj studiji analizirao obrasce financijskog ponašanja velikih američkih poduzeća, te svojim rezultatima i razmišljanjima postavio temelje teorije hijerarhije financijskih izbora (Myers, 1984), dok su artikulaciju i teorijske pretpostavke uobličili Myers \& Majluf (1984), koji se smatraju začetnicima navedene teorije. Prema toj teoriji, zbog asimetričnosti informacija i razlike u pojedinačnim troškovima kapitala, postoji redoslijed korištenja financijskih oblika u financiranju poduzeća: poduzeće će se najprije financirati zadržanim zaradama, zatim emisijom dugova i, na kraju, emisijom nove glavnice. Budući da se vlastiti kapital poduzeća nalazi na prvom i zadnjem mjestu ljestvice, optimalna struktura kapitala prema ovoj teoriji ne postoji, već je postojeća samo odraz kumulativne potrebe poduzeća za financijskim sredstvima.

Navedene teorije, teorija kompromisa i teorija hijerarhije financijskih izbora, smatraju se klasičnim teorijama strukture kapitala, te se upravo one dominantno ispituju u empirijskim istraživanjima. U najvećem broju dostupnih istraživanja testiranje teorija provodi se analizom utjecaja odabranih determinanti strukture kapitala na razinu financijske poluge poduzeća. Zaključci o efikasnosti pojedine teorije u objašnjenju uočenih politika financiranja poduzeća uobičajeno se tada donose na temelju ostvarenog smjera utjecaja pojedinih odrednica za koje ove teorije imaju oprečna očekivanja. Postoji mogućnost i izravnog testiranja teorija, primjenom metode ispitivanja ${ }^{3}$ (najčešće anketnim upitnikom), no takve su studije vrlo rijetke zbog izrazito visokih resursnih zahtjeva i uobičajeno niskih stopa povrata odgovora.

Troškovima agenata smatraju se oportunitetni troškovi nastali zbog djelovanja pojedinih interesnih skupina poduzeća u svrhu zadovoljenja vlastitih interesa, a često na štetu preostalih dionika; uglavnom se odnosi na sukobe između vlasnika i menadžera poduzeća, no nerijetki su sukobi interesa i između drugih interesnih skupina ili pak unutar istih interesnih skupina. Vidjeti detaljnije u Jensen \& Meckling (1976).

2 Pretpostavka teorije agenata jest da se korištenjem duga u financiranju i preuzimanjem obveze plaćanja dospjele glavnice duga i pripadajućih kamata može disciplinirati menadžment prisiljavajući ih na odgovorno upravljanje poduzećem. Naime, povećanjem tereta kamata smanjuje se raspoloživi slobodni novčani tok poduzeća i onemogućava menadžere da njime neefikasno upravljaju.

Referentni primjer takvog istraživanja rad je autora Graham \& Harvey (2001), koji je bio inspiracija za druga slična istraživanja. 
Važan doprinos u mogućnostima istraživanja donose Shyam-Sunder \& Myers (1999) koji u svom radu predstavljaju statistički model teorije hijerarhije financijskih izbora i time omogućavaju istovremeno testiranje navedenih teorija, čime se intenziviraju istraživanja korištenjem tih modela ${ }^{4}$. Autori su na uzorku od 157 američkih kotiranih poduzeća za razdoblje od 1971. do 1989. godine zaključili da je teorija hijerarhije financijskih izbora efikasnija u odnosu na teoriju kompromisa u objašnjenju oblikovanja strukture kapitala analiziranih poduzeća. Adedeji (2002) na primjeru poduzeća izlistanih na Londonskoj burzi za razdoblje od 1994. do 2000. godine zaključuje da se tek 20 - $30 \%$ financijskog deficita poduzeća iz uzorka financira emisijom novog duga, te da je teorija hijerarhije financijskih izbora efikasnija u objašnjenju oblikovanja strukture kapitala poduzeća s visokim razinama financijske poluge, što je suprotno zaključcima u Shyam-Sunder \& Myers (1999). Ivashkovskaya \& Solntseva (2007) na uzorku od 62 velika ruska javna i privatna poduzeća za razdoblje od 2002. do 2005. godine zaključuju da u pojedinačnom testiranju teorije dobro objašnjavaju oblikovanje strukture kapitala, dok se u objedinjenom modelu u kojem se nezavisne varijable obje teorije testiraju istovremeno, prednost daje teoriji hijerarhije financijskih izbora. Lemmon, Roberts \& Zender (2008) na kotiranim američkim poduzećima za razdoblje od 1965. do 2003. godine dobivaju rezultate koji potvrđuju djelovanje teorije kompromisa. Autori zaključuju da poduzeća imaju ciljanu strukturu kapitala kojoj teže, te se prilagodba toj ciljanoj razini odvija emisijom novog duga. Cotei \& Farhat (2009) na uzorku američkih poduzeća za razdoblje od 1980. do 2001. godine zaključuju da teorija kompromisa i teorija hijerarhije financijskih izbora nisu međusobno isključive u oblikovanju strukture kapitala; poduzeća imaju definiran raspon ciljane razine financijskog duga, pri čemu su odstupanja rezultat iskorištavanja tržišnih prilika ili posljedica problema asimetričnosti informacija. Sličan zaključak o međusobnom djelovanju teorija donose i Serrasqueiro \& Nunes (2010) na uzorku portugalskih poduzeća za razdoblje od 1998. do 2006. godine, no ipak ističu da je utjecaj financijskog deficita veći od utjecaja prilagodbe ciljanoj strukturi kapitala, na temelju čega zaključuju da se poduzeća ponašaju više u skladu s teorijom hijerarhije financijskih izbora.

U velikom broju radova autori se usredotočuju isključivo na testiranje teorije hijerarhije financijskih izbora. Tako primjerice Frank \& Goyal (2003), na temelju prethodno predstavljenog rada Shyam-Sundera \& Myersa (1999), na većem uzorku,768 kotiranih američkih poduzeća, i za duži vremenski period, 1971. - 1998., testiraju teoriju hijerarhije financijskih izbora te zaključuju da snaga teorije ovisi o specifikacijama modela i uzorka. Na temelju rezultata, zaključuju da se teorija pokazuje efikasnom za velika, zaduženija poduzeća velikih vrijednosti imovine, dok se snaga teorije smanjuje uključivanjem većeg broja manjih poduzeća u uzorak, što je zapravo suprotno inicijalnim pretpostavkama te teorije. Seifert \& Gonenc (2008) nalaze potvrdu teorije hijerarhije financijskih izbora za poduzeća iz Njemačke, Ujedinjenog Kraljevstva i Sjedinjenih Američkih Država, dok za Japan teorija nije efikasna. Svoje istraživanje autori Seifert \& Gonenc (2006) provode i na primjeru 23 zemlje u razvoju te, suprotno očekivanjima, ne uspijevaju dokazati teoriju hijerarhije financijskih izbora kao primarnu teoriju kojom bi opisali oblikovanje strukture kapitala u svim zemljama. Pokazuju da najveći broj poduzeća financijski deficit financira emisijama nove glavnice, što je suprotno pretpostavkama ove teorije. Ipak, uspijevaju dokazati da je teorija 
efikasna u zemljama gdje su značajno izraženi problemi asimetričnosti informacija i/ili problemi agenata. Lemmon \& Zender (2010) testiraju teoriju na uzorku kotiranih američkih poduzeća za razdoblje od 1971. do 2001. godine i zaključuju da je teorija efikasna za poduzeća koja nisu ograničena kreditnim kapacitetima, dok poduzeća koja su blizu kreditnog kapaciteta financijski deficit financiraju emisijama nove glavnice.

Testiranje teorija na uzorku hrvatskih poduzeća korištenjem modela predstavljenih u radu Shyam-Sunder \& Myers (1999) relativno je oskudno. Šestanović, Horvat \& Tomić (2018) na uzorku od 17 nefinancijskih poduzeća uvrštenih na Zagrebačkoj burzi, za razdoblje od 2008. do 2016. godine, testiraju teoriju hijerarhije financijskih izbora te prihvaćaju postojanje slabog oblika navedene teorije. Pecina (2018) u doktorskoj disertaciji za odabrana hrvatska poduzeća, za razdoblje od 2004. do 2015. godine, provodi testiranje teorije kompromisa i teorije hijerarhije financijskih izbora. Zaključuje da oblikovanje strukture kapitala analiziranih poduzeća u odabranom razdoblju nije moguće isključivo i u potpunosti objasniti jednom od testiranih teorija. Ipak, prednost daje teoriji hijerarhije financijskih izbora jer se za najveći broj godina i za najveći broj poduzeća neovisno o njihovim karakteristikama, ona pokazuje kao teorija koja bolje opisuje oblikovanje financijske politike naspram teorije kompromisa.

Uzevši u obzir nedorečene rezultate provedenih istraživanja, s jedne strane, i važnost implikacija oblikovanja strukture kapitala na vrijednost poduzeća, s druge strane, neosporno je da je ovo područje jedno od najzanimljivijih dijelova financijskog menadžmenta. Kako su teorije razvijene i u najvećem broju ispitane na uzorku velikih kotiranih poduzeća tržišno orijentiranih gospodarstava, dodatna istraživanja na poduzećima različitih karakteristika i u različitim gospodarskim okvirima nužna su kako bi se proširile spoznaje o primjenjivosti postojećih teorija na širem obuhvatu poduzeća. Istraživanjima ovog tipa moguće je premostiti postojeći jaz istraživanja između razvijenih zemalja i zemalja u razvoju te potencijalno pronaći cjelovitije objašnjenje kako poduzeća oblikuju svoju strukturu kapitala. Slijedom navedenog, ovo istraživanje naslanja se na prethodno opisana istraživanja u vidu ispitivanja klasičnih teorija strukture kapitala korištenjem istih statističkih modela i obuhvatom javnih kotiranih poduzeća, no uz određene prilagodbe korištenih varijabli i proširenja uzorka istraživanja. $\mathrm{S}$ obzirom na navedeno, znanstveni doprinos ovog istraživanja ogleda se u (1) proširenju fokusa s dominantno razvijenih tržišta na tržišta u razvoju; (2) proširenju uzorka istraživanja s dominantno javno kotiranih poduzeća na sva velika poduzeća; (3) produbljenju analize istovremenim testiranjem klasičnih teorija naspram dominantnog pristupa pojedinačnog testiranja teorija; (4) prilagodbi ključnih varijabli od interesa sukladno raspoloživim podacima karakterističnima za tržišta u razvoju. Dodatno, važan doprinos ovog istraživanja, značajan ponajprije za domaće gospodarstvo, pronalazi se u relativno većem uzorku istraživanja u odnosu na dosadašnja, prvenstveno, kotirana poduzeća, te činjenici da je ovo jedno od rijetkih ispitivanja $\mathrm{u}$ kojem se teorije testiraju primjenom statističkih modela u odnosu na dominantno ispitivanje teorija pomoću utjecaja odabranih determinanti strukture kapitala. 


\section{METODOLOGIJA I SPECIFIKACIJA MODELA}

U ovoj analizi korišteni su isključivo sekundarni podaci prikupljeni iz baze podataka Financijske agencije (FINA), kojoj su poduzeća dužna po zakonskoj obvezi predavati svoje godišnje financijske izvještaje. Računovodstvena metodologija sastavljanja financijskih izvještaja u promatranom se razdoblju promijenila nekoliko puta, što je rezultiralo usklađivanjem varijabli od interesa prije njihove statističke obrade. Za izračune varijabli korišteni su podaci iz bilance i računa dobiti i gubitka.

Istraživanje se provodi na velikim hrvatskim poduzećima, a odabrana su na način da su u minimalno polovici promatranog razdoblja (dakle, u minimalno 8 od ukupno 16 promatranih godina), sukladno kriterijima propisanima u Zakonu o računovodstvu, klasificirana kao velika poduzeća. U istraživanje su ušla ona velika poduzeća koja su kumulativno zadovoljila sljedeće uvjete:

1. kontinuirano poslovanje u razdoblju od 2004. do 2019. godine, pri čemu nisu bila u blokadi, predstečaju ili stečaju

2. popunjenost stavki izvještaja nužnih za izračune varijabli od interesa

3. pozitivnu vrijednost ukupne imovine, vlasničke glavnice, te prihoda od prodaje u svim godinama promatranja

4. klasifikaciju u sve djelatnosti prema Nacionalnoj klasifikaciji djelatnosti (NKD) 2007., osim poduzeća iz djelatnosti svrstanih u K (Financijski sektor), O (Javna uprava i obrana), T (djelatnost kućanstva), U (izvanteritorijalne organizacije i tijela).

Sukladno navedenim kriterijima u uzorak su uzeta ona poduzeća koja imaju kontinuitet u poslovanju te se u skoroj budućnosti ne očekuje njihova likvidacija. Prema Ang, Cole \& Lawson (2010) poduzeća u financijskim poteškoćama nisu u mogućnosti oblikovati strukturu kapitala sukladno svojim preferencijama, te će njihova struktura kapitala biti rezultat prisile zbog situacije u kojoj se poduzeće nalazi, stoga takva poduzeća treba isključiti iz analize. Nadalje, zahtijeva se pozitivna vrijednost navedenih stavki izvještaja iz praktičnih razloga: te se stavke javljaju kao nazivnici u izračunu varijabli, pa se na ovaj način omogućava njihova adekvatna interpretacija (Hess \& Immenkötter, 2012). Sukladno najvećem broju radova, iz uzorka su izbačena poduzeća gore navedenih djelatnosti jer ona podliježu drugačijim pravilima poslovanja. Kriterije odabira zadovoljila su ukupno 193 poduzeća. Vremenski period istraživanja obuhvaća razdoblje od 2004. do 2019. godine. Za testiranje teorija odabrana je panel analiza, a kako se ista poduzeća prate u svim godinama, riječ je o balansiranom panelu. Tako broj opažanja (N) iznosi (n) $193 *$ (t) $16=$ 3088 poduzeća -godina. Za obradu podataka korišten je statistički paket Stata 13 (verzija Stata/IC 13.1.).

U ovom istraživanju za testiranje teorija strukture kapitala korišteni su modeli predloženi u radu Shyam-Sunder\&Myers (1999), uz nužnu modifikaciju nezavisnih varijabli modela, koja je proizašla prvenstveno iz (ne)dostupnosti svih podataka nužnih za njihov izračun. Za razliku od originalnog rada u kojem se koristi regresijska analiza na presječnim podacima (engl. regression on cross-sectional data), u ovom radu koristi se panel regresijska analiza, a odabir samog modela temelji se na provedenim testovima. 
Model teorije kompromisa, testiran u ovom radu, može se prikazati kao (jednadžba 1):

$$
D_{i, t}=a_{i}+b_{T A}\left(D_{i, t}^{*}-D_{i, t-1}\right)+e_{i, t}
$$

pri čemu $\Delta D_{i t}$ predstavlja godišnju promjenu vrijednosti ukupnog financijskog duga ${ }^{5}$ poduzeća $i$ u vremenu $t, D_{i, t}^{*}$ je ciljana razina ukupnog financijskog duga poduzeća $i$ u vremenu $t$, a $D_{i, t-1}$ ostvarena razina ukupnog financijskog duga poduzeća $i$ u vremenu $t$ - 1 , dok su $e_{i t}$ neovisne identično distribuirane idiosinkratske pogreške, $\varepsilon_{i, t} \sim \operatorname{IID}\left(0, \sigma_{\varepsilon}^{2}\right)$. Izraz $D_{i, t}^{*}-D_{i, t-1}$ obilježava odstupanje ostvarene razine ukupnog financijskog duga poduzeća u prethodnom razdoblju od ciljane razine, koja je aproksimirana, sukladno dominantnom pristupu u dostupnim istraživanjima, prosječnoj vrijednosti financijske poluge konkretnog poduzeća u cjelokupnom promatranom periodu pomnoženoj s vrijednošću ukupnog kapitala poduzeća (da bi se dobila razina financijskog duga) (Shyam-Sunder \& Myers, 1999). Sve varijable skalirane su knjigovodstvenom vrijednošću ukupne imovine (aktive) poduzeća da bi se umanjio utjecaj veličine poduzeća. Prema ovoj teoriji, očekivana vrijednost konstantnog člana, $\alpha_{i}$, je jednaka nuli, dok se za koeficijent teorije kompromisa, $b_{T A}$, očekuje vrijednost u intervalu $<0,1>$. Vrijednost koeficijenta veća od nule upućuje na to da poduzeća prilagođavaju svoju strukturu kapitala ciljnoj razini, dok vrijednost koeficijenta manja od jedan upućuje na to da postoje pozitivni troškovi prilagodbe koji onemogućavaju potpunu i izrazito brzu prilagodbu ciljanoj strukturi kapitala.

Model teorije hijerarhije financijskih izbora korišten u radu zapisuje se kao (jednadžba 2):

$$
D_{i, t}=a_{i}+b_{P O} D E F_{i, t}+e_{i, t}
$$

pri čemu je $\Delta D_{i, t}$ godišnja promjena dugoročnog financijskog duga, a $D E F_{i, t}$ vrijednost financijskog deficita poduzeća $i$ u vremenu $t$. Financijski deficit ${ }^{6}$ je za razliku od svog originalnog oblika, zbog (ne)dostupnosti podataka potrebnih za izračun, u ovom radu izračunat kao razlika novčanog toka poduzeća nakon kamata i poreza $\left(\mathrm{C}_{\mathrm{i}, \mathrm{t}}\right)$, kapitalnih ulaganja $\left(\mathrm{X}_{\mathrm{i}, \mathrm{t}}\right)$ i promjene neto obrtnog kapitala $\left(\mathrm{DW}_{\mathrm{i}, \mathrm{t}}\right)$, odnosno kako slijedi u jednadžbi (3):

$$
\mathrm{DEF}_{\mathrm{i}, \mathrm{t}}=\mathrm{X}_{\mathrm{i}, \mathrm{t}}+\hat{\imath} \mathrm{W}_{\mathrm{i}, \mathrm{t}}-\mathrm{C}_{\mathrm{i}, \mathrm{t}} \text {, }
$$

Također, varijable su skalirane vrijednošću ukupne imovine, slično kao u prethodnom modelu. Prema ovoj teoriji, očekivana vrijednost konstantnog člana, $a_{i}$, jednaka je nuli, dok se za koeficijent teorije hijerarhije financijskih izbora, $b_{P O}$, očekuje jedinična vrijednost u slučaju jakog (engl. strong) oblika, odnosno blizu jedinične vrijednosti u slučaju manje jakog ili slabog (engl. semi-strong) oblika teorije.

Iako struktura kapitala podrazumijeva dugoročne izvore financiranja, u ovom radu koristi se ukupni financijski dug. Naime, dugoročni dug uobičajeno ima i kratkoročnu komponentu (primjerice dio glavnice dugoročnog duga koji se treba podmiriti u narednih godinu dana), kao što redovito obnavljanje kratkoročnog financijskog duga poprima karakteristiku dugoročnosti. U tom je smislu važnije razlikovati financijski (kamatni) i nefinancijski (nekamatni) dug; u ovom radu koristi se isključivo financijski dug, dakle onaj za koji postoji obveza plaćanja odgovarajućih naknada financiranja.

$6 \quad$ Iz izračuna financijskog deficita, zbog nedostupnosti podataka, izostavljene su stavke: (1) dividende i (2) vrijednost dugoročnih dugova koji dospijevaju u tekućem razdoblju. 
Odabir najprikladnijeg modela temeljio se na provedenim statističkim testovima: (1) F-test za odabir između združenog OLS-a i modela s fiksnim efektima, (2) Breush-Paganov test za odabir između združenog OLS-a i modela sa slučajnim efektom, te (3) Sargan-Hansenova $^{7}$ testa za odabir između modela s fiksnim i modela sa slučajnim efektima. Svrha je F-testa provjeriti postoje li pojedinačni efekti. Odbacivanje nulte hipoteze dovodi do zaključka da postoji značajan fiksni efekt, odnosno da je model s fiksnim efektom (FE) poželjniji od združenog OLS modela. Breusch-Paganov LM test ispituje postojanje slučajnih efekata. Nulta hipoteza navodi da su komponente varijance pogreške jednake nuli. Ako se nulta hipoteza ne odbaci, preferira se združeni OLS model. U suprotnom, model sa slučajnim efektom (RE) nadmašuje združeni OLS. Konačno, za odabir između modela s fiksnim (FE) ili slučajnim (RE) efektom proveden je Sargan-Hansenov test s nultom hipotezom da je preferirana specifikacija modela model sa slučajnim (RE) efektom, nasuprot alternativi modela s fiksnim efektom (FE).

U sklopu regresijske dijagnostike, utvrđeno je da postoji problem heteroskedastičnosti i autokorelacije, zbog čega su u analizi prikazane klaster robusne standardne pogreške (engl. cluster robust standard errors), pri čemu su kao varijabla grupiranja u klastere korištene jedinice promatranja, odnosno poduzeća, što je osiguralo konzistentnost standardnih pogrešaka s obzirom na heteroskedastičnost i autokorelaciju (Hoechle, 2007). Stacionarnost varijabli nije testirana jer je analizirani period relativno kratak (Blackburne \& Frank, 2007).

\section{ANALIZA I DISKUSIJA REZULTATA}

U nastavku rada sažeto su prikazani rezultati testiranja teorija strukture kapitala na hrvatskim velikim poduzećima, za vremensko razdoblje od 2004. do 2019. godine. Prednost pojedinoj teoriji u objašnjenju oblikovanja strukture kapitala analiziranih poduzeća u ovom radu dana je na temelju ostvarenih vrijednosti koeficijenata determinacije, $R^{2}$ within za panel modele, odnosno $R^{2}$ za združeni model. Dakako, da bi se pojedina teorija smatrala efikasnom, ostvareni koeficijenti teorija trebali su se pokazati statistički značajnima na razini do $10 \%$.

U tablici 1 sažeto su prikazani rezultati pojedinačnog testiranja teorija $(1-$ teorija kompromisa, 2 - teorija hijerarhije financijskih izbora) za sva velika hrvatska poduzeća, a potom na poduzorcima za dionička, odnosno nedionička poduzeća.

Sargan-Hansenov test koristi se u odabiru između modela s fiksnim i modela sa slučajnim efektima kada se iskazuju robusne ili klaster standardne greške, jer tada nije moguće koristiti uobičajeni Hausmanov test. 
Tablica 1. Sažeti pregled rezultata testiranja teorija strukture kapitala za velika poduzeća

\begin{tabular}{|c|c|c|c|c|c|c|}
\hline & \multicolumn{2}{|c|}{ velika poduzeća } & \multicolumn{2}{|c|}{ dionička društva } & \multicolumn{2}{|c|}{ nedionička društva } \\
\hline & (1) & (2) & (1) & (2) & (1) & (2) \\
\hline model & FE & RE & FE & FE & FE & FE \\
\hline broj opažanja & 3088 & 3088 & 611 & 611 & 2477 & 2477 \\
\hline $\begin{array}{l}\text { broj jedinica } \\
\text { promatranja }\end{array}$ & 193 & 193 & 48 & 48 & 175 & 175 \\
\hline$a_{t}$ & $0,0005^{* * *}$ & $0,0096^{* * *}$ & $0,0029^{* * *}$ & $0,0025^{* * *}$ & $0,0013^{* * *}$ & $0,0064^{* * *}$ \\
\hline $\begin{array}{l}\text { (cluster robust } \\
\text { SE) }\end{array}$ & $(0,0002)$ & $(0,0020)$ & $(0,0004)$ & $(0,0002)$ & $(0,0002)$ & $(0,0014)$ \\
\hline$b_{T A}$ & $0,9123^{* * *}$ & & $0,9773^{* * *}$ & & $0,5594^{* * *}$ & \\
\hline $\begin{array}{l}\text { (cluster robust } \\
\text { SE) }\end{array}$ & $(0,0675)$ & & $(0,0166)$ & & $(0,0565)$ & \\
\hline$b_{P O}$ & & $0,4146^{* * *}$ & & $0,4251^{* * *}$ & & $0,1709^{* *}$ \\
\hline $\begin{array}{l}\text { (clusterrobust } \\
\text { SE) }\end{array}$ & & $(0,0152)$ & & $(0,0037)$ & & $(0,0691)$ \\
\hline R2 within & 0,8799 & 0,8490 & 0,9764 & 0,9720 & 0,3947 & 0,0437 \\
\hline \multicolumn{7}{|l|}{ F-test } \\
\hline $\mathrm{F}$ & 182,54 & 1093,21 & 3463,46 & 13295,11 & 97,89 & 6,12 \\
\hline Prob $>F$ & 0,0000 & 0,0000 & 0,0000 & 0,0000 & 0,0000 & 0,0144 \\
\hline \multicolumn{7}{|l|}{ LM test } \\
\hline chibar2(01) & 0,0000 & 6,3100 & 0,0500 & 0,0000 & 0,0000 & 0,0000 \\
\hline Prob > chibar2 & 1,0000 & 0,0060 & 0,4099 & 1,0000 & 1,0000 & 1,0000 \\
\hline \multicolumn{7}{|l|}{$\begin{array}{l}\text { Sargan-Hansen } \\
\text { test }\end{array}$} \\
\hline SH stat. & 1,9940 & 0,6510 & $\mathrm{RE}$ & $\mathrm{RE}$ & 5,937 & $\mathrm{RE}$ \\
\hline p-value & 0,1579 & 0,4197 & $\begin{array}{l}\text { are } \\
\text { equivalent } \\
\text { to pooled } \\
\text { OLS }\end{array}$ & $\begin{array}{c}\text { are } \\
\text { equivalent } \\
\text { to pooled } \\
\text { OLS }\end{array}$ & 0,0148 & $\begin{array}{c}\text { are } \\
\text { equivalent } \\
\text { to pooled } \\
\text { OLS }\end{array}$ \\
\hline
\end{tabular}

Napomene: $a_{i}$ - konstanta; $b_{T A}$ - koeficijent teorije kompromisa; $b_{P O}$ - koeficijent teorije hijerarhije financijskih izbora; razine signifikantnosti: $* * * 1 \%, * * 5 \%, * 10 \%$

Izvor: izračun autora.

Na temelju rezultata iz tablice 1 može se primijetiti da su konstante i koeficijenti teorija u svim modelima statistički signifikantni na razini od $1 \%$ (tek kod nedioničkih poduzeća u modelu teorije hijerarhije financijskih izbora riječ je od razini od $5 \%$ ). Konstante poprimaju vrijednosti vrlo blizu očekivanim teorijskim vrijednostima, dok se razlike očituju u koeficijentima teorija, koji, iako statistički značajni, nisu poprimili teorijski pretpostavljene jedinične vrijednosti. 
Analizom rezultata dobivenih na ukupnom uzorku promatranih poduzeća može se primijetiti da su modeli obje teorije ostvarili gotovo jednake vrijednosti koeficijenata determinacije, s malom prednosti teorije kompromisa $\left(R_{T A}^{2}=0,8799\right)$ naspram teorije hijerarhije financijskih izbora $\left(R_{P O}^{2}=0,8490\right)$. Iako koeficijent teorije kompromisa nije poprimio očekivanu jediničnu vrijednost, on je visok $\left(b_{T A}=0,8799\right)$, što ukazuje na to da velika hrvatska poduzeća iz uzorka imaju definiranu ciljanu strukturu kapitala, te je nastoje održavati stalnim prilagođavanjem ostvarene razine onoj ciljanoj, pri čemu su te prilagodbe relativno brze. Koeficijent teorije hijerarhije financijskih izbora $\left(b_{P O}\right)$ od 0,4146 upućuje na to da analizirana poduzeća financijski deficit u manjoj mjeri financiraju zaduživanjem naspram vlastitih izvora financiranja, što upućuje na prihvaćanje slabog oblika ove teorije.

Podjelom uzorka na dionička i nedionička poduzeća, mogu se uočiti određene razlike u rezultatima. Koeficijenti determinacije oba modela, teorije kompromisa i teorije hijerarhije financijskih izbora, značajno su viši za dionička poduzeća, pri čemu i dalje blago dominira teorija kompromisa $\left(R_{T A}^{2}=0,9764\right.$ naspram $\left.R_{P O}^{2}=0,9720\right)$. Nadalje, vrijednost koeficijenta teorije kompromisa značajno se približila teorijskoj jediničnoj vrijednosti, te iznosi $b_{T A}=0,9773$, što ukazuje na relativno dobru moguénost objašnjavanja oblikovanja strukture kapitala velikih dioničkih poduzeća teorijom kompromisa. Za razliku od dioničkih društava, kod nedioničkih su poduzeća koeficijenti determinacije značajno niži $\left(R_{T A}^{2}=0,3947 ; R_{P O}^{2}=0,0437\right)$; ipak, i dalje dominira teorija kompromisa, dok izrazito nizak koeficijent determinacije teorije hijerarhije financijskih izvora može ukazivati na nemogućnost objašnjenja oblikovanja strukture kapitala ovom teorijom. Također, za ovu skupinu poduzeća koeficijent teorije kompromisa niži je u odnosu na dionička društva $\left(b_{T A}\right.$ nedionička $=0,5594<b_{T A \text { dionička }}=0,9773$ ), što može upućivati na sporiju prilagodbu ciljanoj strukturi kapitala (u odnosu na dionička društva) uslijed većih transakcijskih troškova. Naime, prema Fisher, Heinkel \& Zechner (1989) transakcijski troškovi prilagodbe ciljanoj strukturi kapitala razlikovat će se ovisno o pojedinim karakteristikama poduzeća. Tako poduzeća kojima se pripisuje veći problem asimetričnosti informacija imaju veća ograničenja u pristupu eksternom financiranju. Prema tome, može se pretpostaviti da će manja transparentnost poslovanja dovesti do većih troškova prilagodbe i sporijih modifikacija strukture kapitala nedioničkih poduzeća.

Kod dioničkih društava koeficijent teorije hijerarhije financijskih izbora viši je u odnosu na isti koeficijent kod nedioničkih poduzeća $\left(b_{P O \text { dionička }}=0,4251>b_{\text {PO dionička }}=0,1709\right)$, što upućuje na to da dionička društva koriste više dugova u financiranju deficita naspram nedioničkih. Ipak, kako je koeficijent determinacije za teoriju hijerarhije financijskih izbora kod nedioničkih poduzeća izrazito nizak $\left(R_{P O}^{2}=0,0437\right)$, ove rezultate treba uzeti s oprezom.

U pojedinačnom testiranju teorija u svim specificiranim modelima prednost se daje teoriji kompromisa kao onoj koja bolje opisuje oblikovanje strukture kapitala velikih hrvatskih poduzeća. Međutim, valja istaknuti nekoliko ograničenja provedenog istraživanja, koja ujedno predstavljaju i moguće pravce budućih analiza. Najprije, vremenski period analize obuhvaća razdoblja različitih gospodarskih uvjeta: ekspanzije, recesije te gospodarskog oporavka. Za pretpostaviti je da su financijske odluke poduzeća i mogućnosti oblikovanja strukture kapitala značajno ovisne o makroekonomskim kretanjima, zbog čega bi ista trebalo uvažiti u istraživanjima. Nadalje, iako su u obzir uzeta velika poduzeća koja su podijeljena na uzorke ovisno o svom pravnom obliku, ona su i dalje međusobno različita po 
nekim drugim karakteristikama, poput pripadnosti industriji, strukturi imovine, tržištima na kojima djeluju, pristupu različitim izvorima financiranja i slično, pa bi bilo poželjno i te različite karakteristike uvrstiti $u$ istraživanja. Obuhvat istraživanja trebalo bi dodatno proširiti na mala i srednja poduzeća, čime bi se s jedne strane, smanjio jaz istraživanja na tim skupinama poduzeća, te dodatno ispitala primjenjivost postojećih teorija izvan onih za koja su teorije inicijalno razvijene.

\section{ZAKLJUČAK}

Struktura kapitala predstavlja jedno od najintrigantnijih područja financijske analize, koje unatoč brojnim istraživanjima i dalje ne nudi jednoznačan odgovor na pitanje kako poduzeća oblikuju svoje strukture kapitala. U osnovi dominiraju dvije teorije za koje se smatra da najbolje opisuju financijske odluke poduzeća, teorija kompromisa i teorija hijerarhije financijskih izbora. Kako su te teorije razvijene i u najvećoj mjeri ispitane na uzorku velikih dioničkih društava tržišno orijentiranih gospodarstava, cilj ovog rada bio je testirati ih na proširenom obuhvatu poduzeća i bitno drugačijem financijskom sustavu. Istovremeno testiranje ovih teorija u danom obliku i za odabrani vremenski period, prema autorovim saznanjima, nije obuhvaćeno prijašnjim empirijskim istraživanjima, te predstavlja određeni iskorak u odnosu na dosadašnja istraživanja na hrvatskom tržištu koja su predstavljena u pregledu istraživanja. Dobiveni rezultati ukazuju na veću efikasnost teorije kompromisa u objašnjenju oblikovanja strukture kapitala analiziranih poduzeća u promatranom vremenskom periodu. Prema tome, poduzeća iz uzorka imaju definiranu ciljanu razinu financijskog duga kojoj konvergiraju. S obzirom na pravni oblik poduzeća, mogu se uočiti određene razlike u oblikovanju strukture kapitala dioničkih i nedioničkih poduzeća. Dok za dionička poduzeća obje teorije pokazuju visoku efikasnost u objašnjenju formiranih struktura kapitala, kod nedioničkih poduzeća dominantna je teorija kompromisa, dok teorija hijerarhije financijskih izbora gubi eksplanatornu snagu. Ovakvi rezultatu u skladu su s rezultatima određenih radova predstavljenih u pregledu literature: (1) slično kao u radu Lemmon, Roberts \& Zender (2008) poduzeća imaju ciljanu razinu duga kojoj teže, što podupire teoriju kompromisa; (2) navedene teorije nisu u potpunosti isključive, dakle primjetno je djelovanje obje teorije slično kao u radovima Cotei \& Farhat (2009) za američka poduzeća i u Pecina (2018) za hrvatska poduzeća; (3) pretpostavlja se postojanje „slabog oblika“ teorije hijerarhije financijskih izbora slično kao u Šestanović, Horvat \& Tomić (2018) za hrvatska kotirana poduzeća, iako je u navedenom radu testirana samo ta teorija; (4) efikasnost pojedine teorije uvelike ovisi o specifičnim karakteristikama poduzeća slično kao primjerice u radovima Frank \& Goyal (2003) za američka poduzeća i Pecina (2018) za hrvatska poduzeća. Naposljetku, valja uvažiti i određena ograničenja provedenog istraživanja, koja ujedno daju smjernice budućim istraživanjima strukture kapitala zemalja u razvoju, a odnose se na uvažavanje različitih faktora vanjskog okruženja i specifičnih karakteristika poduzeća koja neminovno utječu na financijske odluke poduzeća. 


\section{LITERATURA}

Adedeji, A. (2002). A Cross-sectional Test of Pecking Order Hypothesis Against Static Trade-off Theory on UK data. Preuzeto iz University od Birmingham: https://papers. ssrn.com/sol3/papers.cfm?abstract_id=302827

Ang, J., Cole, R. \& Lawson, D. (2010). The Role of Owner in Capital Structure Decisions: An Analysis of Single-Owner Corporations. The Journal of Entrepreneurial Finance, Vol. 14, Issue 3, str. 1-36.

Blackburne, E. F. \& Frank, M. W. (2007). Estimation of nonstationary heterogeneous panels. The Stata Journal 7, No. 2, str. 197-208.

Cotei, C. \& Farhat, J. B. (2009). The Trade-off Theory and the Pecking Order Theory: Are They Mutually Exclusive? North American Journal of Finance and Banking Research, Vol. 3, No. 3, str. 1-16.

Dang, V. A., Kim, M. \& Shin, Y. (2012). Asymmetric capital structure adjustments: New evidence from dynamic panel threshold models. Journal of Empirical Finance, Vol. 19 , str. 465-482.

Donaldson, G. (1961). Corporate debt capacity: a study of corporate debt policy and the determination of corporate debt capacity. Boston: Harvard University.

Fisher, E. O., Heinkel, R. \& Zechner, J. (1989). Dynamic Capital Structure Choice: Theory and Tests. The Journal of Finance, Vol. 44, No. 1, str. 19-40.

Frank, M. Z. \& Goyal, V. K. (2003). Testing the pecking order theory of capital structure. Journal of Financial Economics, Vol. 67, Issue 2, str. 217-248.

Graham, J. R. \& Harvey, C. R. (2001). The theory and practice of corporate finance: evidence from the field. Journal of Financial Economics, Vol.60, str. 187-243.

Hess, D. \& Immenkötter, P. (2012). How Much is Too Much? Debt Capacity and Financial Flexibility. CFR Working Paper No. 14-03, str. 1-66.

Hoechle, D. (2007). Robust standard errors for panel regressions with cross-sectional dependence. The Stata Journal 7, No. 3, str. 281-312.

Ivashkovskaya, I. V. \& Solntseva, M. S. (2007). The Capital Structure of Russian Companies: Testing Trade-off Theory versus Pecking Order Theory. Journal of Corporate Finance, No. 2 (2), str. 17-31.

Jensen, M. C. \& Meckling, W. H. (1976). Theory of the firm: Managerial behavior, agency costs and ownership structure. Journal of Financial Economics, Vol. 3; Issue 4, str. 305-360.

Kraus, A. \& Litzenberger, R. H. (1973). A State-Preference Model of Optimal Financial Leverage. The Journal of Finance, Vol. 28, No. 4, str. 911-922.

Lemmon, M. L. \& Zender, J. F. (2010). Debt Capacity and Tests of Capital Structure Theories. Journal of Financial and Quantitative Analysis, Vol. 45, No. 5, str. 1161-1187.

Lemmon, M. L., Roberts, M. R. \& Zender, J. F. (2008). Back to the Beginning: Persistence and the Cross-Section of Corporate Capital Structure. The Journal of Finance, Vol. LXIII, No. 4, str. 1575-1608.

Modigliani, F. \& Miller, M. H. (1958). The Cost of Capital, Corporate Finance and the Theory of Investment. American Economic Review, Vol. 48 (2), str. 261-297. 
Modigliani, F. \& MIller, M. H. (1963). Corporate Income Taxes and the Cost of Capital: A Correction. The American Economic Review, Vol. 53 (3), str. 433-443.

Mollik, A. T. (2008). Corporate Capital Structure and Firm Value: A Panel Data Evidence from Australia's Dividend Imputation Tax System. U C.-F. Lee, Advances in Quantitative Analysis of Finance and Accounting, Vol. 6 (str. 205-237). Singapore: World Scientific.

Myers, S. C. \& Majluf, N. S. (1984). Corporate financing and investment decisions when firms have information that investors do not have. Journal of Financial Economics, Vol. 13, Issue 2, str. 187-221.

Myers, T. C. (1984). The Capital Structure Puzzle. The Journal of Finance, Vol. 39, No. 3, str. 575-592.

Orsag, S. (2015). Poslovne financije. Zagreb: Avantis, HUFA.

Pecina, E. (2018). Oblikovanje strukture kapitala i identifikacija ograničenja financiranja hrvatskih poduzeća. Doktorski rad. Sveučilište u Zagrebu, Ekonomski fakultet.

Seifert, B. \& Gonenc, H. (2006). Pecking Order Behavior in Emerging Markets. SSRN Electronic Journal.

Seifert, B. \& Gonenc, H. (2008). The International Evidence on the Pecking Order Theory. Journal of Multinational Financial Management 18(3), str. 244-260.

Serrasqueiro, Z. \& Nunes, P. M. (2010). Are trade-off and pecking order theories mutually exclusive in explaining capital structure decisions? African Journal of Business Management, Vol. 4, No. 11, str. 2216-2230.

Shyam-Sunder, L. \& Myers, S. C. (1999). Testing static trade off against pecking order models of capital structure. Journal of Financial Economics, Vol. 51, str. 219-244.

Šestanović, A., Horvat, Đ. \& Tomić, B. (2018). Ispitivanje teorije hijerarhije financijskih izbora na hrvatskom tržištu kapitala. Ekonomski pregled, 69 (1), str. 58-72.

Wooldridge, J. M. (2010). Econometric analysis of cross section and panel data. MIT Press. 